\title{
Implications of the main mathematical methods on marketing decision making process
}

\author{
Ioana Olariu, Assistant Professor PhD Student, \\ University "Vasile Alecsandri" of Bacău, Romania
}

\begin{abstract}
Decision analysis incorporates both the awareness of decision makers, which is located between total confidence and total ignorance and action values assigned to outcomes variants, meaning decision makers preferences. Marketing actions are often insecure. Under these conditions, to achieve the desired result, the company management shall have decision analysis models based on mathematical theories developed in recent decades. Decision analysis is the procedural and formal logic highlights include decision makers a situation and a number of techniques that determine the selection of a solution which solves the problem. Methodological approach of this process serves to form makers options.
\end{abstract}

\section{Keywords:}

Decision, decision making process, mathematical methods.

\section{JEL Code: M31}

\section{Decision and marketing decision making}

Interpreted as systemic models, decisions on well-structured marketing problems are systems that have inputs and outputs. In these models, marketing strategies, expressing controllable by management actions interact with the market environment but in which the company is uncontrollable. Although the company influences some extent certain aspects of the market, however this process has limited significance and can be considered only long-term and only to a limited extent.

The structure of decision-making situations includes the following components ${ }^{1}$ :

a) the use of strategies or actions planned marketing efforts and other resources of the company, or combinations of controllable factors;

b) market ambiance uncontrollable variables, called state of nature;

c) forecasts as probability of occurrence of each state of nature;

d) the consequences or results that occur when there is a certain ambience;

d) decision criterion according to which all information held will be used to choose the strategy that will be applied to solve the problem.

Decision theory is applicable to all types of decision situations. Each decision problem is a single system with different content and involving different responsibilities.

\footnotetext{
${ }^{1}$ Demetrescu, M.C. (2000), Metode de analiză în marketing, Teora Publishing House, Bucharest, p. 179
} 


\section{Decision making under certainty}

Decisions under certainty refers to situations where, following marketing actions will produce one result. As such, every action possible to generate a single specific monetary outcome, which is known as there is only one state of nature, whose manifestation in the future is known with certainty by the decision maker. Solving decision models under certainty is done by selecting the strategy that produces the best result. Thus, the problem of choosing an action is transformed into a problem of selecting between consequences. Since the financial results can be measured degree of achievement of the objective which the various actions are to attain the highest monetary outcome is the best criterion for evaluation can be found mainly achieve it. Decision rule is therefore to choose those actions that result in the largest monetary consequence. The maximization of cash income, for instance, sales, or market share benefit and so on, but subject to the above restrictions that affect search and information concerning costs, time, cognitive ability and analytical decision maker, market and organizational conditions of the enterprise. These restrictions are very important because the information search process should be included, even if decisions under certainty, the determination of significant variables that come into the decision model and setting specific values of these input variables. Since decisions under certainty certainly require knowledge of the state of nature will occur, the only difficulty that presents these decisions is the large number of possible strategies, in this case is the need to use methods of operational research, such as: linear programming, additive method, the method of global utility, the ELECTRE method, LEADER method, ONICESCO method, the method of the coefficient K, ratio method, decision-making table method, the ROMPEDET method. Deployment decision making under certainty requires: maintaining a normal flow of information considered, such as the elements involved are controllable variables and their evolution can be predicted accurately. In this case the decision maker is certain that events will evolve so that once the action started, it will coincide perfectly with some model information that he acquired before the onset of the action.

\section{Approach decisions under uncertainty}

Uncertainty refers to doubt that creates the appearance of a future event. Under uncertainty decision should be based on specific criteria evaluated. It can be used several criteria: conservative or pessimistic - Wald, Laplace criterion, Savage criterion, Hurwicz criterion ${ }^{2}$. The main sources that generate uncertainty are: quality of information, incompleteness of information and reliability of inference (it is often impossible to give precise correlation between observed facts and conclusion to be inferred). To solve such undetermined problems, it may apply game theory models, fuzzy logic, probability theory.

Partial decisions under uncertainty are most often found in marketing. For many times, the decision maker has some information so that it is in an intermediate position between the total lack of information and knowledge of the likelihood of states of nature. Decisions under the total lack of information ${ }^{3}$ are those in which alternative actions lead to consequences that unknown probabilities. Such situation arises when there is a basis of past experience to estimate the likelihood of significant natural state. Lack of information on probabilities, can exist in each phase of the decision.

\footnotetext{
${ }^{2}$ Rațiu-Suciu, C. (2009), Modelare \& simulare economică - breviar, Economic Publishing House, Bucharest, p. 25

${ }^{3}$ Demetrescu, M.C. (2000), Metode de analiză în marketing, Teora Publishing House, Bucharest, p. 199
} 


\section{Approach of decisions under risk}

Attitude can be neutral (linear) risk acceptance (convex curve), or rejection - cautious towards risk (concave curve). In practice, the manager has a flexible behavior, the curve representing the attitude towards risk is partially convex, concave part (alternate).

The methods of measuring the degree of risk you can use the decision tree theory and processes for complex economic simulation technique ${ }^{4}$. It is necessary that any decision problem, to analyze the consequences of each alternative with great responsibility, seeking the most rational way of handling. Management entities often are in a position to make decisions without reliable information on the occurrence of certain events. Consequently, the development of decision-making takes place in the interpretation of economic information in terms of probabilities of the occurrence of natural conditions, resulting, significant deviations from initially expected results.

\section{Group decisions}

Decision solving situations involves many times work groups within organizations. Group decisions have certain advantages: a group comes generally with more and better alternative than one person, group decision making is based on common and diverse experience of its members, while one person is not and may be used only personal experience, stronger group members support the implementation of joint decision, which can be a real advantage for the manager.

There are some disadvantages of group decisions: the decision takes time (to listen and analyze point of view of each member) for consumption entails significant costs, not always reach a decision group better than individually. There are times when the need to preserve friendly relations negatively affects group decision. Optimal decisions to use Group: simple majority method, method utilities, electric methods dimensional algorithm Deutch and Martin etc.

\section{Marketing decisions in conflict}

Decisions in conflict ${ }^{5}$ refer to the decisions made to one or more rational opponents rather than to the state of nature, as if making in situations of risk and uncertainty. Before deciding on an issue, opponents carefully consider rational decision maker.

Under conditions of risk and uncertainty, the states of nature are independent of the selection strategy maker. In conflict, this independence does not exist, because the state of nature instead of opponents appears with an interest contrary to that of the decision maker. Game theory classifies decisions in conflict based on the number of opponents and the degree of opposition of interests.

\section{Conclusions}

Content changes taking place in business entities, require a dynamic decision making, continuous improvement. Through rigorous delimitation of authority and responsibility, clear wording chances of problems in each area of activity, significantly reducing the area. An important role in information domain plays has improving indicators and parameters considered in evaluating decision alternatives. Each decision version, regardless of its nature, will be assessed through a uniform system of indicators so that it could be known all the implications it will have in their practical realization. The emergence of multi-criteria

\footnotetext{
${ }^{4}$ Idem, p. 24

${ }^{5}$ Ibidem, p. 210
} 
and multi operational models and their application in practice is an important step in improving decision-making of economic units. Given the large number of decision problems that are addressed in terms of risk and uncertainty, the use of specific methods of the decision will help to improve decision-making economic units.

\section{Bibliografie}

1. Ackoff, R.L.; Sasieni, M.W. (1975), Bazele cercetării operaționale, Tehnica Publishing House, Bucharest

2. Balaure, V., Adăscăliței, V., Bălan, C., Boboc, Şt., Cătoiu, I., Olteanu, V., Pop, N.A., Teodorescu, N. (2002), Marketing, Uranus Publishing House, Bucharest

3. Demetrescu, M.C. (2000), Metode de analiză în marketing, Teora Publishing House, Bucharest

4. Dumitrescu, M.A.; Niculescu, C. (2001), Teoria deciziei şi cercetare operațională, Niculescu Publishing House, Bucharest

5. Feldman, E.F., Lehrer, T.L. (1966), Warehouse Location Under Continuous Economies of Scale, în „Management Science” XII

6. Green, E.P., Tull, S.D. (1970), Research for Marketing Decision, Prentice-Hall, Inc., Englewood Cliffs, New Jersey

7. Kaufmann, A. (1967), Metode şi modele ale cercetării operaționale, vol. I, Scientific Publishing House, Bucharest

8. Kuehn, A.A., Hamburger, M.J., (1963), A Heuristic Program for Locating Warehouses, în "Management Science", IX

9. Nicolescu, O. (1980), Economia şi conducerea intreprinderii industriale, Didactic and Pedagogical Publishing House, Bucureşti

10. Rațiu-Suciu, C. (2009), Modelare \& simulare economică - breviar, Economic Publishing House, Bucharest. 